\title{
Monitoring LFCN damage during scoliosis surgery
}

\author{
Negar Behzadi Fard ${ }^{1 *}$, Aleksandra Krajacic ${ }^{2}$, Francois D Roy ${ }^{3}$, Sarah Southon ${ }^{2}, K^{2}$ Kaja Duke ${ }^{1,4}$ \\ From The 10th Meeting of the International Research Society of Spinal Deformities (IRSSD 2014 Sapporo) \\ Sapporo, Japan. 29 June - 2 July 2014
}

\section{Objective}

During scoliosis surgery damage to the lateral femoral cutaneous nerve (LFCN) has been reported in $20 \%$ of patients. The purpose of this study was to characterize intraoperative pressures at the patient cushion interface and examine the LFCN somatosensory evoked potential (SSEP) to determine if there is any correlation to the incidence of LFCN injury.

\section{Material and methods}

Three pressure mats (FSA, Vista Medical, Winnipeg) were placed on the Jackson frame before positioning the patient. Data was continuously recorded during surgery and the average and maximum pressures on the chest, left and right hip/thigh region was calculated (Figure 1). The LFCN SSEP was tested by stimulating the anterolateral thigh and recording the evoked potentials over the somatosensory cortex. An increase in latency and/or decrease in SSEP amplitude may be indicative of LFCN dysfunction. At present, data on five patients was recorded. Post-operative evaluation of the front of the iliac crests is performed and the appearance of redness (Figure 2), blisters or pressure sores are documented.
Additionally, after surgery, the patients were asked if they feel any numbness on the front of the thighs and manual tests for sensation were performed every day until discharge.

\section{Results}

The continuous monitoring was interrupted during electrocautery. The changes in pressure on the chest pads were able to detect cyclic breathing. Increases in pressure were also noted at times such as screw placement or correction. Maximum and average pressure for the five cases is shown in Table 1. LFCN SSEP recordings were variable and the preliminary results are inconclusive. Two patients had numbness in one leg post-op. One of the injuries resolved on day four and the other was still evident on discharge.

\section{Conclusions}

Pressure on the LFCN during scoliosis surgery caused numbness in $2 / 5$ patients. Pressure mats were able to record changes during surgery. More data is required to determine if there is any correlation between elevated pressure and LFCN injury.

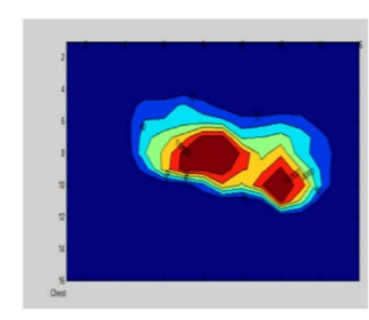

a)

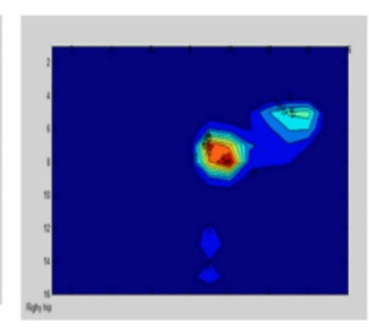

b)

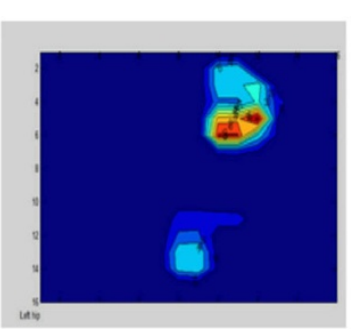

c)

Figure 1 Sample pressure mat data on the a) Chest b) left hip area and c) right hip area

${ }^{1}$ Department of Mechanical Engineering, University of Alberta, Canada

Full list of author information is available at the end of the article 


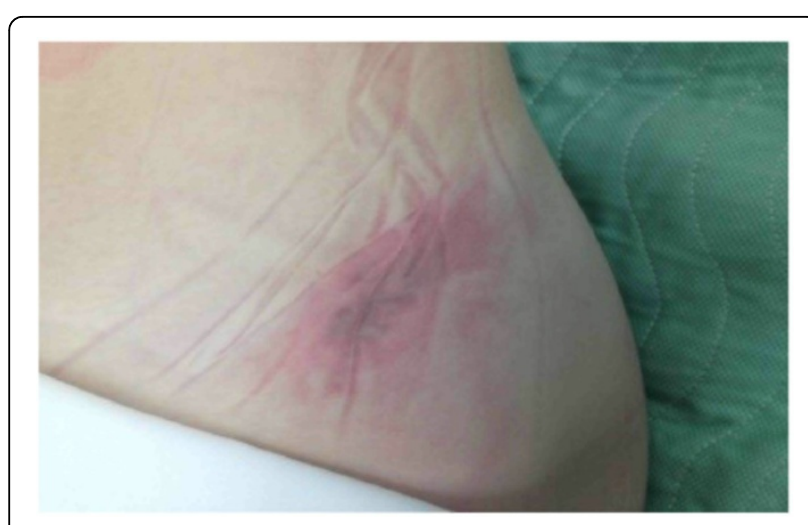

Figure 2 Redness over the iliac crest after surgery

Table 1 Average and maximum pressures for the five cases

\begin{tabular}{cccccccc}
\hline & \multicolumn{2}{c}{ chest } & \multicolumn{2}{c}{ Left hip } & \multicolumn{2}{c}{ Right hip } \\
\hline Case & $\begin{array}{c}\text { Average } \\
(\mathrm{mmHg})\end{array}$ & Max & $\begin{array}{c}\text { Average } \\
(\mathrm{mmHg})\end{array}$ & Max & $\begin{array}{c}\text { Average } \\
(\mathrm{mmHg})\end{array}$ & Max & $\begin{array}{c}\text { Duration } \\
\text { (hours })\end{array}$ \\
\hline 1 & 51 & 310 & 23 & 175 & 22 & 357 & $6 \mathrm{~h} 3 \mathrm{tf}$ \\
\hline 2 & 42 & 220 & 29 & 303 & 34 & 371 & $6 \mathrm{hhl5}^{\prime}$ \\
\hline 3 & 68 & 310 & 29 & 199 & 27 & 313 & $4 \mathrm{~h}^{\prime \prime} 7^{\prime}$ \\
\hline 4 & 51 & 291 & 18 & 240 & 26 & 319 & $6 \mathrm{hO2}^{\prime}$ \\
\hline 5 & 49 & 148 & 26 & 222 & 21 & 517 & 5 h23' $^{\prime}$ \\
\hline
\end{tabular}

\section{Consent}

Written informed consent was obtained from the patient for the image(s) used in this study. A copy of the written consent is available for review by the Editor of this journal.

\section{Authors' details}

'Department of Mechanical Engineering, University of Alberta, Canada.

${ }^{2}$ Alberta Health Services, University of Alberta Hospital, Canada. ${ }^{3}$ Department

of Surgery and Centre for Neuroscience, University of Alberta, Canada.

${ }^{4}$ Division of Orthopaedic Surgery, University of Alberta, Canada.

Published: 19 January 2015

\section{Submit your next manuscript to BioMed Central} and take full advantage of:

- Convenient online submission

- Thorough peer review

- No space constraints or color figure charges

- Immediate publication on acceptance

- Inclusion in PubMed, CAS, Scopus and Google Scholar

- Research which is freely available for redistribution

Submit your manuscript at www.biomedcentral.com/submit 